\title{
Effects of Triphenyltin on Fish Early Life Stages
}

\author{
K. Fent ${ }^{1}$, W. Meier ${ }^{2}$ \\ ${ }^{\prime}$ Swiss Federal Institute for Environmental Science and Technology (EAWAG), Ueberlandstrasse 133, CH-8600 Dübendorf, Switzerland \\ ${ }^{2}$ University of Berne, Institute of Animal Pathology, Länggass-Strasse 122, CH-3012 Berne, Switzerland
}

27 October 1993/Revised: 28 February 1994

\begin{abstract}
Using a static-renewal procedure, effects of triphenyltin chloride (TPT) on hatching, survival, and morphology were assessed in early life stages of European minnows Phoxinus phoxinus. Embryonic-larval exposure at 16 and $21^{\circ} \mathrm{C}$, and larval exposure at $16^{\circ} \mathrm{C}$ were compared. In the embryoniclarval exposure at $16^{\circ} \mathrm{C}$, hatching was delayed and hatching success decreased at $15.9 \mu \mathrm{g} / \mathrm{L}$. Mortality increased at $\geqslant 3.9$ $\mu \mathrm{g} / \mathrm{L}$ TPT, and complete mortality occurred after 7 and 9 days at 15.9 and $5.1 \mu \mathrm{g} / \mathrm{L}$, respectively. Mortality was higher at $21^{\circ} \mathrm{C}$ that at $16^{\circ} \mathrm{C}$. Triphenyltin was more toxic to fish in larval stages. The induced effects were dose related, mortality increased at $1.8 \mu \mathrm{g} / \mathrm{L}$ after 3 days, and was total after 5 days at $10.6 \mu \mathrm{g} / \mathrm{L}$. In all high TPT exposures, larvae developed skeletal malformations (bent tails), showed impaired swimming behavior or paralysis, and eyes became opaque. Marked histopathological alterations were found. Degenerative hydropic vacuolation of the cytoplasm were evident in skeletal muscles, skin, kidneys, corneal epithelium, lens, pigment layer of the retina and choroid, retina, and CNS including spinal cord. In severe cases, nuclear changes including pycnosis and karyorrhexis occurred. The observed toxicity of TPT was similar to that of tributyltin, but TPT acted more selectively on the lens and CNS, whereas other tissues were less affected. The study indicates that Phoxinus phoxinus larvae are negatively affected at peak TPT concentrations found in polluted environments.
\end{abstract}

Triphenyltin (TPT) compounds are used as a cotoxicant to tributyltin in antifouling paints on vessels, subsequently leading to contamination of aquatic ecosystems. These compounds are also used in agriculture as fungicides for the protection of crops against fungal diseases, as rodent and insect repellants, and as molluscicides. Both direct release into the water from antifouling paints and agricultural applications in rice fields, as well as runoff from agricultural fields are prone to contaminating aquatic environments. Pollution of freshwaters (Fent and Hunn 1991; Stäb et al. 1993) and marine environments (Alzieu et al. 1991) by TPT have been reported. Concentrations of up to $0.2 \mu \mathrm{g} / \mathrm{L}$ TPT were detected in boat harbors (Fent and Hunn 1991 ), and $1.5 \mu \mathrm{g} / \mathrm{L}$ in a ditch adjacent to a potato field after routine spraying with TPT fungicides (Stäb et al. 1993). Organotin containing antifouling paints have been regulated in several countries which has resulted in a decrease of pollution (e.g., Alzieu et al. 1989). There are, however, still levels of TPT present both in freshwaters (Fent and Hunn 1994) and marine environments (Alzieu et al. 1991; Shiraishi and Soma 1992) that are considered to be of ecotoxicological relevance.

Toxicological studies on the effects of this compound are needed, since the contamination of aquatic systems by trace levels of TPT is not only restricted to certain sites. The possible effects of TPT compounds, particularly on freshwater ecosystems, are not fully understood, mainly because ecotoxicological research and monitoring have been focused on the toxic tributyltin (TBT) compounds. Toxic effects of TPT on aquatic organisms may be serious after application in rice fields (Schaefer et al. 1981), and seem to occur at the same order of magnitude as those of TBT (for review, Hall and Pinkney 1985). Moreover, the pharmacokinetics of both compounds is similar (Tsuda et al. 1987; Fent et al. 1991).

Early life stages of fishes are known to be very vulnerable to pollutants (Weis and Weis 1989). In rainbow trout yolk sac fry, $5.8 \mu \mathrm{g} / \mathrm{L}$ triphenyltin chloride caused acute mortality, which was complete within 14 days of exposure, and a no-observableeffect concentration (NOEC) of $0.05 \mu \mathrm{g} / \mathrm{L}$ TPT was proposed (de Vries et al. 1991). For TPT hydroxide, an $\mathrm{LC}_{50}(96 \mathrm{~h})$ of $7.1 \mu \mathrm{g} / \mathrm{L}$ was reported in fathead minnow (Pimephales promelas) larvae (Jarvinen et al. 1988). Furthermore, TPT was found to be rapidly accumulated, only very slowly eliminated, and apparently not metabolized in European minnows (Phoxinus phoxinus) larvae (Fent et al. 1991).

In this study, the effects of triphenyltin chloride on survival of the early life stages of European minnows, Phoxinus phoxinus, gross morphology and histology were investigated. Minnows are found in most European streams and in some lakes, particularly where there is a gravel bottom. They are typical fish of upland streams, being found in the Alps to high altitudes, although also found in the smaller rivers of lowland plains. In the summer, they are pelagic and shoal near the surface. Spawning takes place in May over gravelly shallows. 
The small eggs ( $1.5 \mathrm{~mm}$ in diameter) get attached to the stones or drop onto the loose gravel. The diet varies with the size of fish, the time of the year, and the available food (zooplankton, chironomids, insects and their larvae, filamentous algae). Phoxinus phoxinus is an important inhabitant of European freshwaters, if only because of its abundance. It is widely preyed on by many piscivorous birds and also features in the diet of certain fishes. Minnows may reside at sites that are prone to contamination by organotin compounds, and exposure may take place via water and/or food. The objectives of this study were to investigate the effects of TPT in a representative European freshwater fish at different life stages (embryos and larvae) and at different temperatures, as well as to determine effects of organotins on freshwater fish that spawn and recruit at the time of the year (spring) where organotin pollution is highest. Sensitive toxicological parameters such as histopathology were included to evaluate subtle adverse effects and target organs of this toxicant. The results show that the effects of TPT are similar to those of TBT, which indicates a more general effect pattern of organotins on the early life stages of freshwater fishes.

\section{Materials and Methods}

\section{Water and Triphenyltin}

Characteristics of the water used for the experiments were dissolved organic carbon $0.7-1.0 \mathrm{mg} / \mathrm{L}$, pH $7.8-7.9$, total phosphorus $3 \mu \mathrm{g} / \mathrm{L}$, $\mathrm{SiO}_{2} 1.7 \mathrm{mg} / \mathrm{L}, \mathrm{NO}_{3} 640 \mu \mathrm{g} / \mathrm{g}$, and $\mathrm{NH}_{4}$ below the detection limit. Triphenyltin chloride (TPT) was purchased from Fluka AG, Buchs, Switzerland, with a purity of $>97 \%$. In the TPT stock solution used for spiking lake water, $0.9 \mu \mathrm{g}$ TPT per $\mathrm{ml}$ acetone was determined by chemical analysis with high resolution gas chromatography with flame photometric detection. In addition, traces of impurities, diphenyltin (DPT) and monophenyltin (MPT), were found.

\section{Experimental Procedure}

Adult Phoxinus phoxinus were caught in the river Le Doubs, Switzerland, and held in ponds in a hatchery. Eggs were stripped from gravid females and fertilized with sperms from mature males in May 1989. Prior to exposure, all unfertilized eggs were removed. Incubations of embryos and larvae took place in glass Petri dishes (diameter $9.5 \mathrm{~cm}$ ) holding $50 \mathrm{ml}$ water in climate chambers in the dark. Two different exposure procedures were made. In the embryonic-larval experiment, 24-h-old fertilized embryos were exposed, and in the larval experiment, newly hatched yolk-sac larvae were used. In the embryoniclarval experiment, exposure took place at 16 and $21^{\circ} \mathrm{C}$ for 9 and 5 days, respectively, and in the larval experiment at $16^{\circ} \mathrm{C}$ for 5 days. Early life stages of minnows were randomly distributed among different dose groups, each of them consisting of three replicates of 30 eggs or 15 larvae. The egg density per dish on a weight bases was in the range of $3.5-4.5 \mathrm{~g} / \mathrm{L}$, and the larval density was $1.2-1.5 \mathrm{~g} / \mathrm{L}$.

The exposure concentrations were selected on the basis of both environmental contamination and comparison with effects induced by tributyltin (Fent and Meier 1992). The lowest exposure concentration chosen was close to maximal levels of $1.5 \mu \mathrm{g} / \mathrm{L}$ found in freshwaters (Stäb et al. 1993). In the embryonic-larval exposure, concentrations were between 0.9 and $18.2 \mu \mathrm{g} / \mathrm{L}$ TPT at $16^{\circ} \mathrm{C}$, and 9.1 and $18.2 \mu \mathrm{g} / \mathrm{L}$ at $21^{\circ} \mathrm{C}$. In the larval exposure at $16^{\circ} \mathrm{C}$, nominal TPT concentrations were between 4.5 and $18.2 \mu \mathrm{g} / \mathrm{L}$. Lake water was spiked with appropriate quantities of a stock solution of triphenyltin chloride in acetone $(0.1 \mathrm{mg} / \mathrm{ml} \mathrm{TPT})$, or acetone alone in the solvent control $(0.1 \mathrm{ml} / \mathrm{L})$.
Acetone in concentrations used in these experiments did not affect hatching, survival, and histology of larvae (Fent 1992; Fent and Meier 1992). Water was changed and TPT was renewed every $48 \mathrm{~h}$. Dissolved oxygen content and $\mathrm{pH}$, periodically determined, were in the ranges of 70-100\% and 7.8-8.0, respectively. Embryos and hatched larvae were examined daily under a dissection microscope for abnormalities, behavior, and mortality. Dead embryos and larvae were removed from the Petri dishes. Hatching was defined as disruption of the chorion. No food was provided for the yolk-sac larvae.

At the end of the experiments, larvae were preserved in $10 \%$ formalin for later histological investigations. Preserved larvae were embedded in paraffin, and 4-6 $\mu \mathrm{m}$ thick sections were hematoxylin-eosin stained using standard methods (Meier and Pfister 1981). Organs and tissues were examined histopathologically in longitudinal and cross whole-body sections.

Differences in hatching and survival between controls and exposed groups at different days of exposures were tested by means of a chisquare test with significance limits of $p \leqslant 0.05$.

\section{Phenyltin Analysis}

In order to determine actual exposure concentrations, 50 or $100 \mathrm{ml}$ aliquots of water samples were taken during the whole exposure period at the beginning $(0 h)$ and before water renewal $(48 h)$. The respective 0 and $48 \mathrm{~h}$ water samples were pooled separately in glass bottles, acidified to $\mathrm{pH} 2$, stored at $4^{\circ} \mathrm{C}$ in the dark until analysis, and analyzed for phenyltins by high-resolution capillary gas chromatography with flame photometric detection. The analytical method is based on a slightly modified procedure of Müller (1987), and details are given by Fent and Hunn (1991). Briefly, phenyltins were extracted from water after spiking with internal standards tripropyltin and pentyltins using diethylether and hexane (2:3) with $0.25 \%$ tropolone. After ethylation by a Grignard reaction, phenyltins were analyzed using a $30 \mathrm{~m}$ fused-silica column (DB-5). The detection limit was $0.02-0.1 \mu \mathrm{g} / \mathrm{L}$ in the $100 \mathrm{ml}$ water sample. All values in this paper are given as the $\mathrm{Phe}_{3} \mathrm{Sn}^{+}$(TPT), $\mathrm{Phe}_{2}$ $\mathrm{Sn}^{2+}$ (DPT), and $\mathrm{PheSn}^{3+}$ (MPT) ion, and corrected for recovery by internal standards.

\section{Results}

\section{Exposure Concentrations}

Organotin concentrations in experimental waters decreased during the exposure period to $72 \%$ (range $52-90 \%$ ) of initial values (Table 1), similar to previous experiments with TBT (Fent 1992; Fent and Meier 1992). This was mainly due to the incorporation of triphenyltin into fish, as adsorption to glassware and loss by evaporation were insignificant. Consequently, in this paper averages between initial concentrations and before water exchange were taken as the exposure concentrations. They were on average $71 \%$ (range 29-95\%) of nominal values (Table 1). In addition to TPT, traces of DPT and MPT in the range of $0.02-0.5 \mu \mathrm{g} / \mathrm{L}$ were recorded due to impurities in the stock solution. Such traces do not account for the toxic effects observed, as diphenyltin and monophenyltin chlorides are 2-3 orders of magnitude less toxic than triphenyltin chloride (Brüschweiler and Fent 1994). The analytical results show the importance of the determination of actual experimental water concentrations.

\section{Embryonic-Larval Exposure at Two Temperatures}

Minnow embryos began to hatch 3 days after the start of the exposure, and hatching was completed within 5-6 days in con- 
Table 1. Measured triphenyltin (TPT) concentrations $(\mu \mathrm{g} / \mathrm{L})$ in experimental water

\begin{tabular}{|c|c|c|c|c|}
\hline Experiment & $\begin{array}{l}\text { TPT } \\
\text { nominal }\end{array}$ & $\begin{array}{l}\text { Sampling } \\
\text { time }\end{array}$ & $\begin{array}{l}\text { TPT } \\
\text { measured }\end{array}$ & $\begin{array}{l}\text { TPT } \\
\text { average }\end{array}$ \\
\hline \multirow{10}{*}{ Embryonic-larval, $16^{\circ} \mathrm{C}$} & \multirow[t]{2}{*}{0} & $0 \mathrm{~h}^{\mathrm{a}}$ & $n d^{c}$ & \\
\hline & & $48 h^{b}$ & nd & nd \\
\hline & \multirow[t]{2}{*}{0.9} & $0 \mathrm{~h}$ & 0.3 & \\
\hline & & $48 \mathrm{~h}$ & 0.2 & 0.2 \\
\hline & \multirow[t]{2}{*}{4.5} & $0 \mathrm{~h}$ & 4.1 & \\
\hline & & $48 \mathrm{~h}$ & 3.7 & 3.9 \\
\hline & \multirow[t]{2}{*}{9.1} & $0 \mathrm{~h}$ & 5.9 & \\
\hline & & $48 \mathrm{~h}$ & 4.3 & 5.1 \\
\hline & \multirow[t]{2}{*}{18.2} & $0 \mathrm{~h}$ & 16.3 & \\
\hline & & $48 \mathrm{~h}$ & 15.4 & 15.9 \\
\hline \multirow[t]{6}{*}{ Embryonic-larval, $21^{\circ} \mathrm{C}$} & \multirow[t]{2}{*}{0} & $0 \mathrm{~h}$ & nd & \\
\hline & & $48 \mathrm{~h}$ & nd & nd \\
\hline & \multirow[t]{2}{*}{9.1} & $0 \mathrm{~h}$ & 8.6 & \\
\hline & & $48 \mathrm{~h}$ & 4.5 & 6.6 \\
\hline & \multirow[t]{2}{*}{18.2} & $0 \mathrm{~h}$ & 15.1 & \\
\hline & & $48 \mathrm{~h}$ & 13.3 & 14.2 \\
\hline \multirow[t]{8}{*}{ Larval, $16^{\circ} \mathrm{C}$} & \multirow[t]{2}{*}{0} & $0 \mathrm{~h}$ & nd & \\
\hline & & $48 \mathrm{~h}$ & nd & nd \\
\hline & \multirow[t]{2}{*}{4.5} & $0 \mathrm{~h}$ & 2.2 & \\
\hline & & $48 \mathrm{~h}$ & 1.5 & 1.8 \\
\hline & \multirow[t]{2}{*}{9.1} & $0 \mathrm{~h}$ & 6.8 & \\
\hline & & $48 \mathrm{~h}$ & 3.7 & 5.2 \\
\hline & \multirow[t]{2}{*}{18.2} & $0 \mathrm{~h}$ & 12.3 & \\
\hline & & $48 \mathrm{~h}$ & 9.0 & 10.6 \\
\hline
\end{tabular}

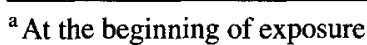

${ }^{b}$ After $48 \mathrm{~h}$ of exposure

${ }^{\mathrm{c}}$ Not detected

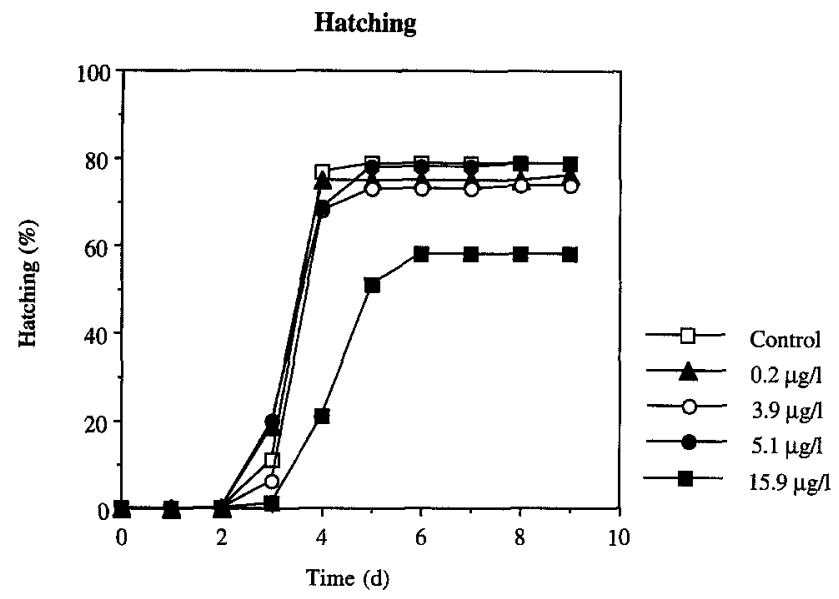

Fig. 1. Hatching of European minnows (Phoxinus phoxinus) larvae after embryonic-larval exposure to various determined aqueous TPT concentrations at $16^{\circ} \mathrm{C}$. Hatching was significantly reduced at 15.9 $\mu \mathrm{g} / \mathrm{L}$ TPT at $16^{\circ} \mathrm{C}(\mathrm{p}<0.01)$

trols and TPT-exposed fish when held at $16^{\circ} \mathrm{C}$ (Figure 1). Hatching was not affected up to $5.1 \mu \mathrm{g} / \mathrm{L}$ TPT, but delayed at $15.9 \mu \mathrm{g} / \mathrm{L}$. At this concentration, hatching success was significantly reduced to $58 \%$ (chi-square $\mathrm{p}<0.01$ ). In controls, and at lower concentrations, hatching success was 76-79\%. A significant increase in mortality (chi-square $\mathrm{p}<0.001$ ) was observed after 7 days when the minnows were exposed to a concentration of $3.9 \mu \mathrm{g} / \mathrm{L}$ and above. Mortality was increased after hatching, and was $100 \%$ after 9 days of exposure to 5.1

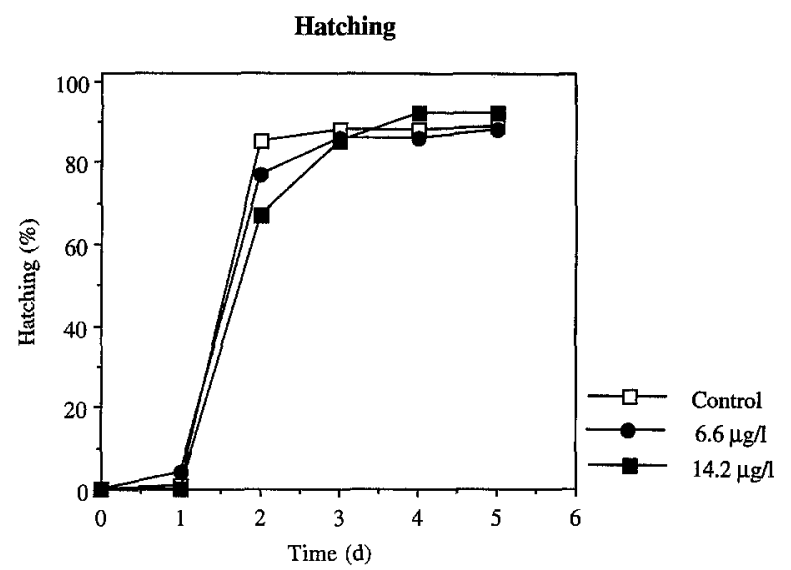

Fig. 2. Hatching of European minnows (Phoxinus phoxinus) larvae after embryonic-larval exposure to 6.6 and $14.2 \mu \mathrm{g} / \mathrm{L}$ TPT at $21^{\circ} \mathrm{C}$. Each dose group consisted of three replicates with about 30 eggs each

$\mu \mathrm{g} / \mathrm{L}$ TPT. However, at $15.9 \mu \mathrm{g} / \mathrm{L}$ mortality was higher prior to hatching, and was complete after 7 days.

Embryonic development was faster at $21^{\circ} \mathrm{C}$. Hatching began after 1 day, but was slightly delayed at the high dose as compared to controls and low dose (Figure 2). There were no significant differences in hatching success among groups (chisquare $\mathrm{p}>0.05$ ). Triphenyltin exposure resulted in a significant increase in larval mortality at $\geqslant 6.6 \mu \mathrm{g} / \mathrm{L}$ after 3 days ( $\mathrm{p}<0.05$ ), and mortality was $100 \%$ after 5 days at 6.6 and $14.2 \mu \mathrm{g} / \mathrm{L}$. In comparison to $16^{\circ} \mathrm{C}$, TPT-induced mortality was greater at the higher temperature; yolk-sac larvae died shortly after hatching.

\section{Larval Exposure}

In a second series of experiments, newly hatched yolk-sac larvae were exposed to TPT in order to compare its toxic effects on larvae with those on embryos. After 3 days of exposure to $10.6 \mu \mathrm{g} / \mathrm{L}, 30 \%$ of the larvae showed gross morphological alterations, and mortality was significantly increased (chisquare $p<0.001$ ) compared to controls. After 5 days of exposure, mortality increased significantly at $1.8 \mu \mathrm{g} / \mathrm{L}$ (chi-square $\mathrm{p}<0.01$ ), and complete and $98 \%$ mortality were observed at 10.6 and $5.2 \mu \mathrm{g} / \mathrm{L}$, respectively.

Direct comparison of these results with those obtained after exposure to TBT (Fent 1992; Fent and Meier 1992) shows that the acute toxicity of both compounds are in the same order of magnitude, although TPT was slightly less toxic both after embryonic-larval and larval exposure.

\section{Behavioral and Gross Morphological Effects}

Morphological and behavioral effects were noted at $16^{\circ} \mathrm{C}$ in exposed yolk-sac larvae in the embryonic-larval and larval exposures at TPT concentrations of 3.9 and $1.8 \mu \mathrm{g} / \mathrm{L}$, respectively, and higher. All larvae at $21^{\circ} \mathrm{C}$ were abnormal after exposure to $14.2 \mu \mathrm{g} / \mathrm{L}$ TPT at hatching (second day of exposure), and $60 \%$ were abnormal after 4 days of exposure to 6.6 $\mu \mathrm{g} / \mathrm{L}$ TPT. Some larvae in all but the low-dose exposures showed erratic swimming behavior with subsequent immobili- 

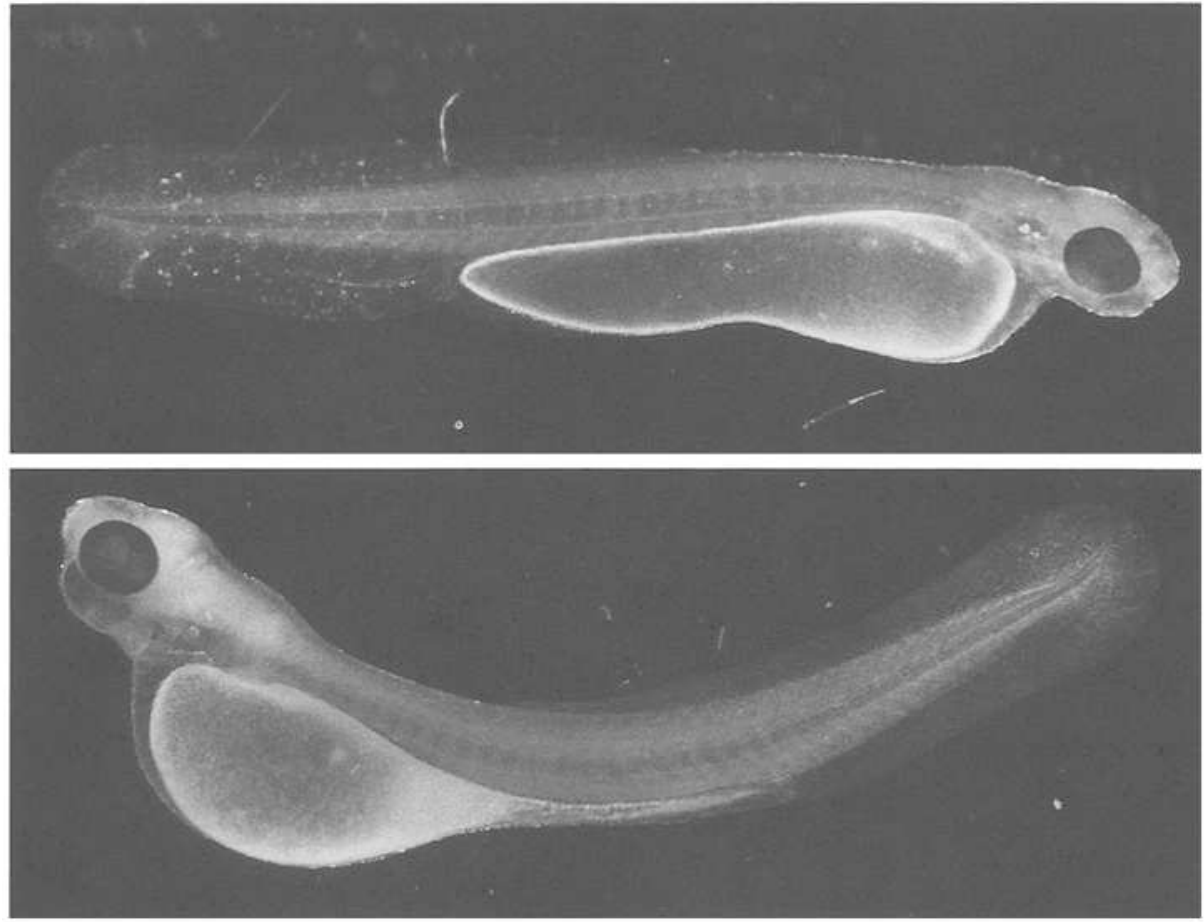

Fig. 3. Morphological effects of TPT on Phoxinus phoxinus yolk-sac larvae after exposure at $16^{\circ} \mathrm{C}$. Control larva (top) and larva exposed to a TPT concentration of $5.1 \mu \mathrm{g} / \mathrm{L}$ (below). Note the malformation of the vertebral axis (lordosis) and retarded yolk-sac resorption zation, or they were paralyzed. In general, larvae showed reduced motility and were lethargic, except at the lowest TPT doses. Many yolk-sac larvae had a crippled shape due to an abnormal vertebral axis (bent tails) with pronounced ventral curvatures (lordosis) (Figure 3 ). In some cases, deformed body axes were associated with retarded yolk-sac resorption, and edema in the heart region. Furthermore, about $70 \%$ of the high dose larvae became opaque eyes.

\section{Histopathological Effects}

In TPT-exposed larvae, degenerative cellular changes and alterations in various tissues including skeletal muscles, skin, kidneys, corneal epithelium, lens, pigment layer of the retina and choroid, retina, and CNS including spinal cord were observed. No changes were evident in intestinal tissues. Degenerative alterations were found at concentrations of 3.9 and 1.8 $\mu \mathrm{g} / \mathrm{L}$ TPT and higher in the embryonic-larval and larval exposure, respectively, and they were related to the dose. In the affected tissues, hydropic degeneration (vascuolar degeneration), and degenerative nuclear changes including pyknosis, karyorrhexis, and karyolysis, or even focal necrosis were evident. The TPT-induced effects were essentially similar to those induced by TBT (Fent and Meier 1992). However, TPT acted more selectively on the CNS and spinal cord, retina, and the eye lens, whereas effects on skin, skeletal muscles, and kidneys were less marked. In the following section, TPT-induced effects are described in relation to TBT-induced effects, and emphasis is placed on the illustration of TPT-related alterations.

Degenerative changes in the skin such as hydropic vacuolation was observed in the cytoplasm of epithelial cells at 5.1 $\mu \mathrm{g} / \mathrm{L}$ and higher. In more pronounced cases at higher concentrations $(>5.1 \mu \mathrm{g} / \mathrm{L} \mathrm{TPT})$, nuclear alterations, and also erosion of the epithelium occurred. In skeletal muscles, alterations ranging from hydropic swelling to myocytolysis were evident. They occurred at higher TPT concentrations as with TBT. Tubulonephrosis in the kidneys was seen at $5.1 \mu \mathrm{g} / \mathrm{L}$, and at higher concentrations. In the eye, marked degenerative effects on the lens were most prominent (Figure 4). Disintegration of collagen fibers and vacuolation were observed. In addition, the cornea and corneal epithelium, as well as the retina showed degenerative changes such as hydropic vacuolation and nuclear alterations. The amount of pigment in the pigment layer of the retina and choroid was reduced depending on the TPT dose. All these histological changes resulted in the occurrence of opaque eyes in high-dose exposed larvae.

Severe, diffuse hydropic vacuolation occurred in the brain (Figure 5) and in the spinal cord. Alterations in cellular structures were more pronounced than with TBT (Fent and Meier 1992). As in other tissues, degenerative effects included nuclear alterations (pycnosis, karyorrhexis) in severe cases. In the other organs, either no alterations were found, or the number of histological sections (liver) were too small to examine, or the tested larval organs (gills) were not yet adequately differentiated to allow an accurate investigation.

\section{Discussion}

This study demonstrates toxic effects of triphenyltin chloride on the early life stages of European minnows Phoxinus phoxinus which are common and important inhabitants of European riv ers and lakes. Toxic effects, such as delayed hatching, reduced survival, gross morphological, and histological alterations were dependent on temperature and the stage of development. A reduced hatching rate was found at the highest TPT dose at $16^{\circ} \mathrm{C}$, but not at $21^{\circ} \mathrm{C}$. This difference likely lies in the different duration of the exposure periods. Comparisons show that the 

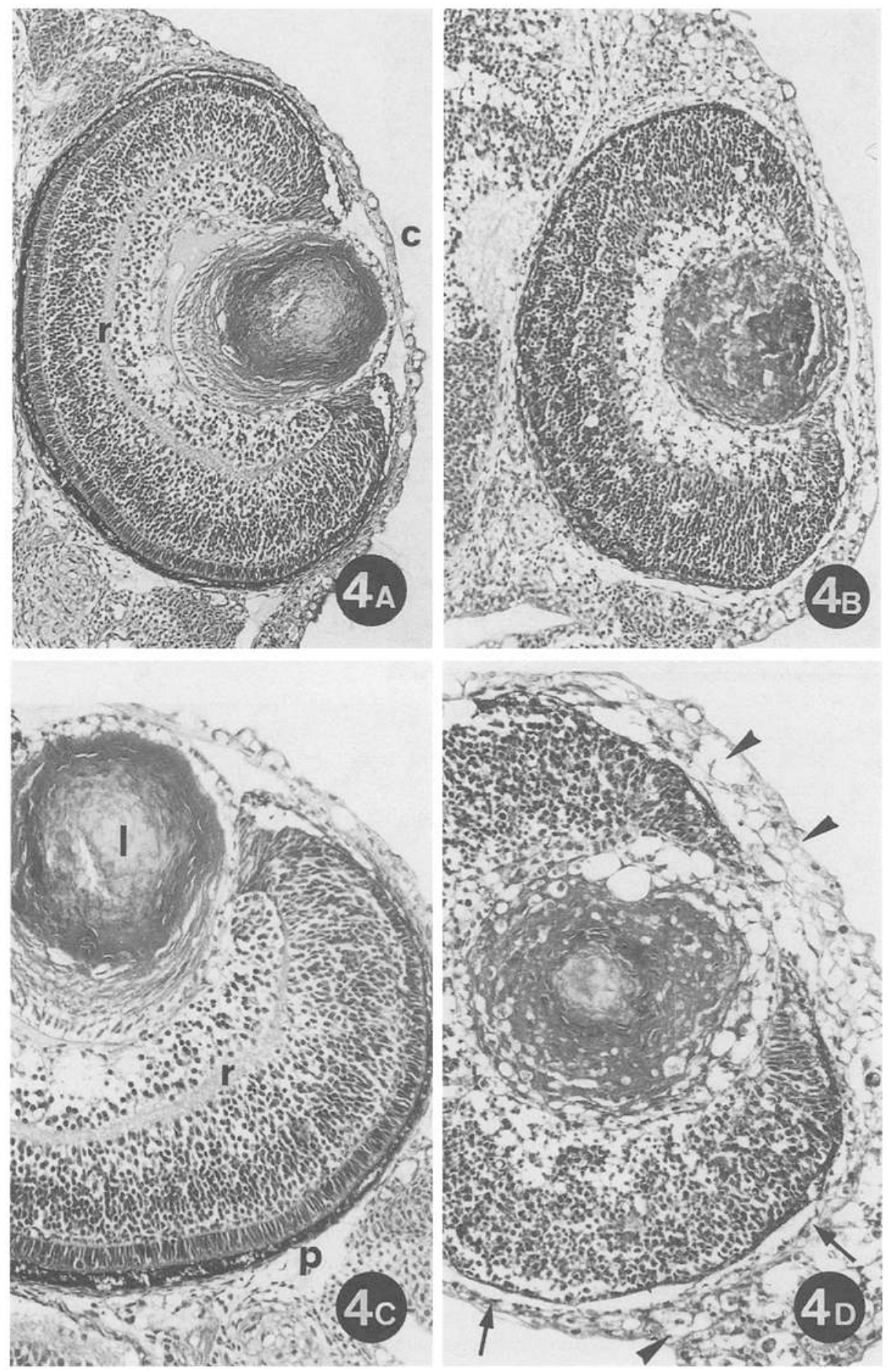

Fig. 4. Eyes of Phoxinus phoxinus larvae. $\mathrm{HE}, 400 \times(\mathrm{A}, \mathrm{B}) ; 700 \times$ (C,D). A,C Sections of control fish: corneal epithelium (c); lens (1); retina (r); pigment layer (p). B,D Sections of fry (3 days) exposed to $5.1 \mu \mathrm{g} / \mathrm{L}$ TPT. Edematic vacuolization and necrosis of individual cells within the surface epithelium $(\Delta)$, marked hydropic degenerative alteration in the lens, loss of architecture in the retinal part of the eye together with a widespread depigmentation ( $\uparrow$ ) effects were more pronounced after larval that embryonic-larval exposure. Survival and morphology were adversely affected at $1.8 \mu \mathrm{g} / \mathrm{L} \mathrm{TPT}$ in the larval and $3.9 \mu \mathrm{g} / \mathrm{L}$ in the embryonic-larval exposure. The reduced toxicity in embryos was most likely due to the protection of these life stages by the chorion. This is consistent with the bioaccumulation kinetics of TPT in these fish; the uptake was significantly increased after the embryos have hatched, and clearance and metabolism were extremely slow if not absent (Fent et al. 1991). Hence, the observed toxic effects are related to the incorporation and absorption of TPT.

The observed toxicity of TPT in European minnows (Phoxinus phoxinus) larvae is similar to fathead minnows (Pimephales promelas) larvae, and rainbow trout (Oncorhynchus mykiss) larvae (de Vries et al. 1991). Jarvinen et al. (1988) found an $\mathrm{LC}_{50}(96 \mathrm{~h})$ of $7.1 \mu \mathrm{g} / \mathrm{L}$ triphenyltin hydroxide, reduced survival at $2 \mu \mathrm{g} / \mathrm{L}$, and a reduced growth at $0.23 \mu \mathrm{g} / \mathrm{L}$ after 30 days of exposure in fathead minnows. Similarly, in the present 


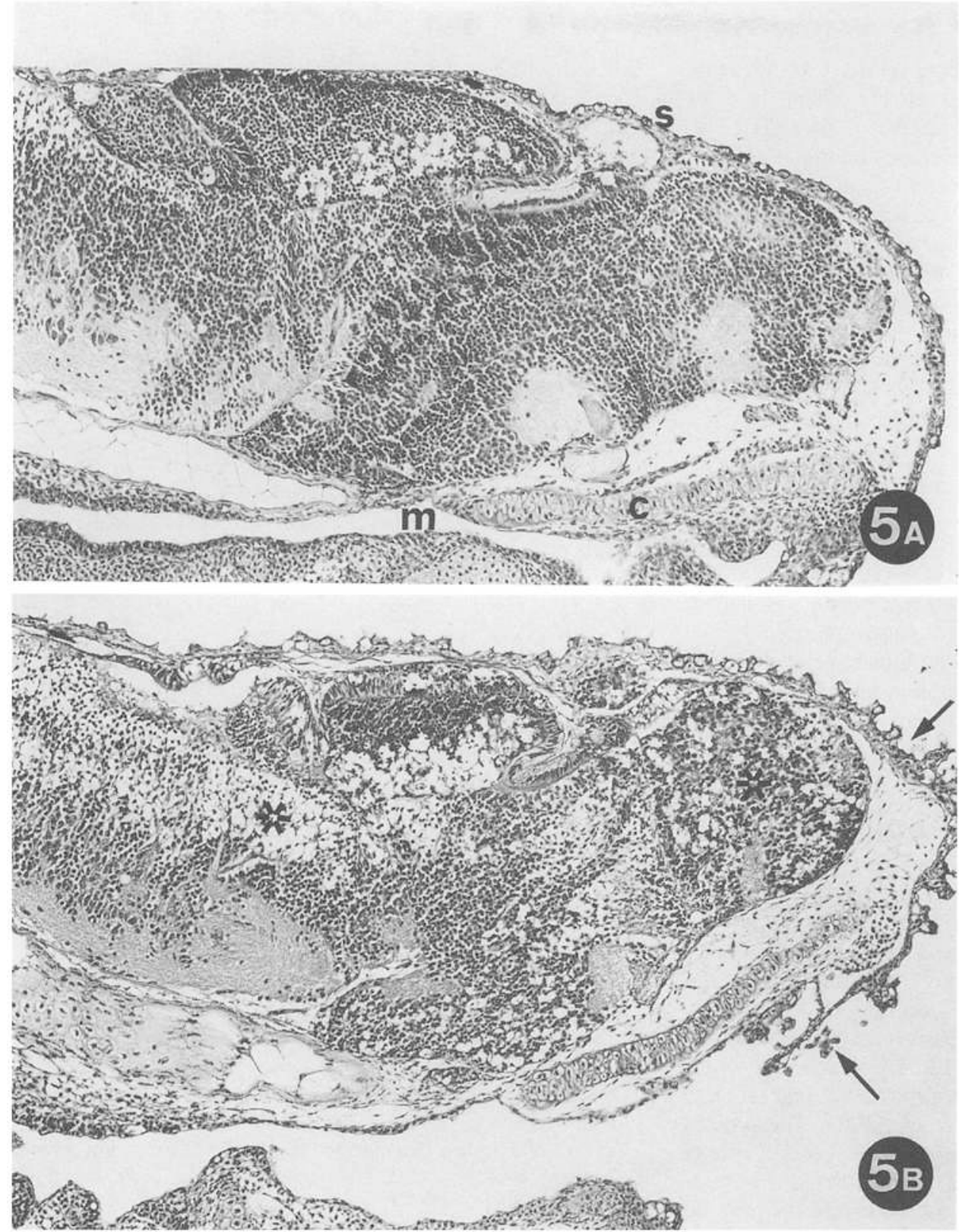

Fig. 5. Saggital section of the brain of Phoxinus phoxinus larvae. HE, $400 \times$. A Section of control fry: cartilage (c); mouth cavity (m); skin (s). B Section of fish exposed to 5.1 $\mu \mathrm{g} / \mathrm{L}$ TPT (8 days). Marked hydropic vacuolization of the poorly differentiated central nervous system (*); irregular shape and erosion of the skin epithelium ( $\uparrow$ ) study survival of Phoxinus was significantly reduced at 3.9 $\mu \mathrm{g} / \mathrm{L}$ in the embryonic-larval, and $1.8 \mu \mathrm{g} / \mathrm{L}$ in the larval exposure. From the above description it is evident that TPT is very toxic to the early life stages of different fish.

\section{Histopathology}

Histopathology is a sensitive tool for the detection of subtle effects of pollutants, elucidation of target organs, and possible toxic mechanisms. The ability to qualitatively and/or quantitatively determine cellular changes prior to death of the organism can often provide early indications of toxicity, and valuable insights into the mechanisms of toxicity. Therefore, data on cellular and histologic alterations are increasingly being used as a biomarker for exposure to environmental contaminants in field studies. This information along with biochemical data may provide a more complete and accurate description of the toxic mechanisms. Although histopathology has often been used in studies on juvenile or adult fish exposed to TBT (Chliamovitch and Kuhn 1977; Wester and Canton 1987; Schwaiger et al. 1992), it is only rarely used in fish early life stages. Our previous study on the embryotoxicity of TBT demonstrated significant and pronounced histologic effects on a number of larval organs (Fent and Meier 1992).

In the present study, histologic alterations occurred in different tissues at $\geqslant 3.9 \mu \mathrm{g} / \mathrm{L}$ and $\geqslant 1.8 \mu \mathrm{g} / \mathrm{L}$ TPT in the embryoniclarval and larval exposures, respectively. The effects on various cells in different organs are likely to be caused by a cytotoxic mode of action, and are not considered as a teratogenic effect. Dose related degenerative alterations were noted in skin, skeletal muscles, kidneys, eyes, and CNS. In the eyes, various 
tissues were affected including cornea, retina, choroid, lens, and pigment layer of the retina. These effects explain the cataracts observed in the high-dose larvae. At $0.2 \mu \mathrm{g} / \mathrm{L} \mathrm{TPT}$, no histologic changes were evident in European minnows Phoxinus phoxinus. Similarly, no degenerative alterations were found at a nominal concentration of $0.8 \mu \mathrm{g} / \mathrm{L}$ TPT after a 110 days exposure in rainbow trout yolk-sac fry (de Vries et al. 1991). However, at $1.8 \mu \mathrm{g} / \mathrm{L}$ TPT Phoxinus larvae were negatively affected. As such concentrations may occur in freshwaters (Stäb et al. 1993), early life stages of this and other fishes may be negatively affected in such environmental compartments.

\section{Comparison with Higher Vertebrates}

Various effects observed in the early life stages of fishes are similar to those reported in higher vertebrates including man (Bock 1981). Acute TPT intoxication in a person resulted in severe ataxia, encephalopathy and delayed polyneuropathy (Wu et al. 1990). Severe ataxia and prominent cerebellar dysfunction, as well as axonal degeneration and demyelination were observed. Another study reported an occurrence of aneuploidy in human peripheral lymphocytes (Jensen et al. 1991). In other mammals, TPT compounds led to immunotoxic effects including increased susceptibility to infection. Reduced lymphopoiesis, reduction of thymus and spleen weight, and atrophy of the white pulp of the spleen and of the thymus were observed in guinea pigs (Verschuuren et al. 1966; Verschuuren et al. 1970) and rats (Snoeij et al. 1985). Further effects were irritation of the skin and eye (cited in Zuckerman et al. 1978), decreased fertility (testicular atrophy, reduced size of the ovary), but no teratogenic effects occurred (Giavini et al. 1980). Decreased resistance to bacterial challenge was also found in young rainbow trout after 133 days of exposure to 0.2 $\mu \mathrm{g} / \mathrm{L} \mathrm{TPT}$, at a concentration where growth and survival were also negatively affected (de Vries et al. 1991). The present study shows that in early life stages of certain species of fishes, similar effects such as neurotoxicity and epithelial irritations occurred as in higher vertebrates, but other effects may be species and age-dependent.

\section{Similarity of Triphenyltin and Tributyltin}

The toxicities of TBT and TPT in early life stages of Phoxinus phoxinus were essentially similar as revealed by survival data, morphology, and histopathology. Similar cellular alterations in the same target tissues were noted after exposure to both tributyltin and triphenyltin chlorides, but potencies towards some of these organs were different. Compared to TBT (Fent 1992; Fent and Meier 1992), the acute toxicity of TPT was slightly lower. Moreover, the effects of TPT on the skin, muscles, kidneys, and eye tissues (cornea, retina, pigment layer) were less marked, but the lens was seriously affected. Triphenyltin chloride also showed a higher affinity to neural tissues, but a lower irritation property to surface epithelia. Reasons for these differences are not known, but they may be related to the different molecular structures, octanol-water partition coefficients (log Kow), and modes of action of these compounds. The log Kow's for tributyltin chloride and triphenyltin chloride at $\mathrm{pH}$
7.8 were 3.83 and 3.46 , respectively (Tsuda et al. 1990). It should be emphasized, however, that TBT and TPT share similar toxicities, target organs, and pharmacodynamics (Fent et al. 1991; Fent 1992; Fent and Meier 1992), rather than marked differences.

In conclusion, TPT and TBT are similar in their potential hazards to larval fish. Hence, it would be unwise to replace TBT by TPT in antifouling paints. As freshwater ecosystems and coastal waters are still contaminated by both TBT and TPT due to the use in antifouling paints and use in agriculture (TPT), potential impacts of these organotin compounds on fish are still a matter of concern.

Acknowledgments. This paper is dedicated to the memory of Professor G. Zbinden. We thank J. Hunn for assistance in the TPT analyses, and P. Landolf for providing the fish.

\section{References}

Alzieu C, Sanjuan J, Michel P, Borel M, Dreno JP (1989) Monitoring and assessment of butyltins in Atlantic coastal waters. Mar Pollut Bull 20:22-26

Alzieu C, Michel P, Tolosa I, Bacci E, Mee LD, Readman JW (1991) Organotin compounds in the Mediterranean: a continuing cause for concern. Mar Environ Res 32:261-270

Bock R (1981) Triphenyltin compounds and their degradation products. Residue Rev 79:1-270

Brüschweiler BJ, Fent K (1994) Unpublished results.

Chliamovitch YP, Kuhn C (1977) Behavioral, haematological and histological studies on acute toxicity of bis(tri- $n$-butyltin) oxide on Salmo gairdneri Richardson and Tilapia rendalli Boulenger. J Fish Biol 10:575-585

de Vries H, Penninks AH, Snoeij NJ, Seinen W (1991) Comparative toxicity of organotin compounds to rainbow trout (Oncorhynchus mykiss) yolk sac fry. Sci Total Environ 103:229-243

Fent K (1991) Bioconcentration and elimination of tributyltin chloride by embryos and larvae of minnows Phoxinus phoxinus. Aquat Toxicol 20:147-158

(1992) Embryotoxic effects of tributyltin on the minnow Phoxinus phoxinus. Environ Pollut 76:187-194

Fent K, Hunn J (1991) Phenyltins in water, sediment, and biota of freshwater marinas. Environ Sci Technol 25:956-963

Fent K, Meier W (1992) Tributyltin-induced effects on early life stages of minnows Phoxinus phoxinus. Arch Environ Contam Toxicol 22(4):428-438

Fent K, Hunn J (1994) Unpublished results.

Fent K, Lovas R, Hunn J (1991) Bioaccumulation, elimination and metabolism of triphenyltin chloride by early life stages of minnows Phoxinus phoxinus. Naturwissenschaften 78:125-127

Giavini E, Prati M, Vismara C (1980) Effects of triphenyltin acetate on pregnancy in the rat. Bull Environ Contam Toxicol 24:936-939

Hall LW Jr, Pinkney AE (1985) Acute and sublethal effects of organotin compounds on aquatic biota: an interpretative literature evaluation. CRC Crit Rev Toxicol 14:159-207

Jarvinen AW, Tanner DK, Kline ER, Knuth ML (1988) Acute and chronic toxicity of triphenyltin hydroxide to fathead minnows (Pimephales promelas) following brief or continuous exposure. Environ Pollut 52:289-301

Jensen KG, Andersen O, Rønne M (1991) Organotin compounds induce aneuploidy in human peripheral lymphocytes in vitro. Mut Res 246:109-112.

Meier W, Pfister K (1981) Viral hemorrhagic septicemia (VHS) in pike 
(Esox lucius L.): Clinical, macroscopic, histological and electronmicroscopical findings. Direct visualization of the Esten-virus. Schweiz Arch Tierheilk 123:27-49

Müller MD (1987) Comprehensive trace level determination of organotin compounds in environmental samples using high-resolution gas chromatography with flame photometric detection. Anal Chem 59:617-623

Schaefer CH, Miura T, Dupras JEF, Wilder WH (1981) Environmental impact of the fungicide triphenyltin hydroxide after application to rice fields. J Econ Entomol 74:597-600

Schwaiger J, Bucher F, Ferling H, Kalbfus W, Negele RD (1992) A prolonged toxicity study on the effects of sublethal concentrations of bis(tri- $n$-butyltin)oxide (TBTO): histopathological and histochemical findings in rainbow trout (Oncorhynchus mykiss). Aquat Toxicol 23:31-48

Shiraishi H, Soma, M (1992) Triphenyltin compounds in mussels in Tokyo Bay after restriction of use in Japan. Chemosphere 24:1103-1109

Snoeij NJ, Van Iersel AAJ, Penninks AH, Seinen W (1985) Toxicity of triorganotin compounds: Comparative in vivo studies with a series of trialkyltin compounds and triphenyltin chloride in male rats. Toxicol Appl Pharmacol 81:274-286

Stäb JA, Cofino WP, van Hattum B, Brinkman UAT (1993) Comparison of GC/MSD and GC/AED for the determination of organotin compounds in the environment. Fresenius J Anal Chem 347:247255
Tsuda T, Nakanishi H, Aoki S, Takebayashi J (1987) Bioconcentration and metabolism of phenyltin chlorides in carp. Water Res 21:949953

Tsuda T, Aoki S, Kojima M, Harada H (1990) The influence of $\mathrm{pH}$ on the accumulation of tri- $n$-butyltin chloride and triphenyltin chloride in carp. Comp Biochem Physiol 95C:151-153

Verschuuren HG, Kroes R, Vinck HH, Van Esch GJ (1966) Short-term toxicity studies with triphenyltin compounds in rats and guineapigs. Food Cosmetic Toxicol 4:35

Verschuuren HG, Ruitenberg EJ, Peetom F, Helleman PW, Van Esch GJ (1970) Influence of triphenyltin acetate on lymphatic tissue and immune responses in guinea pigs. Toxicol Appl Pharmacol $16: 400-410$

Weis JS, Weis P (1989) Effects of environmental pollutants on early fish development. CRC Rev Aquat Sci 1:45-73

Wester PW, Canton JH (1987) Histopathological study of Poecilia reticulata (guppy) after long-term exposure to bis(tri- $n$-butyltin) oxide (TBTO) and di- $n$-butyltindichloride (DBTC). Aquat Toxicol 10:143-165

Wu RM, Chang YC, Chiu HC (1990) Acute triphenyltin intoxication: A case report. J Neurol Neurosurg Psychol 53:356-357

Zuckerman JJ, Reisdorf RR, Ellis HV, Wilkinson RR (1978) Organotins in biology and the environment. In: Brinckman FE, Bellama JM (eds) Organometals and organometalloids: Occurrence and fate in the environment. Americal Chemical Society, Washington, DC, pp 388-422 